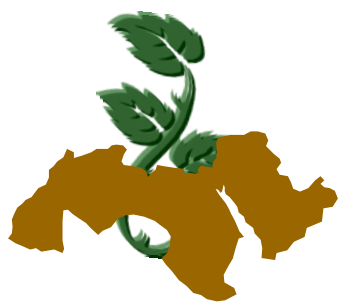

\title{
EFFECT OF POULTRY MANURE AND NITROGEN BIO-FERTILIZER (NITROBEN) ON GROWTH, YIELD AND CHEMICAL CONTENTS OF SQUASH PLANTS
}

\author{
El-Bassiony', A.M.; Z.F. Fawzy' ${ }^{1}$ and S.A. Saleh ${ }^{2}$ \\ 1. Vegetable Research Department, National Research Centre, Dokki, Cairo, Egypt. \\ 2. Horticulture Technology Department, National Research Centre, Dokki, Cairo, Egypt
}

Keywords: Squash, Biofertilizer, Poultry manure, Growth, Yield, Chemical contents.

\begin{abstract}
Two field experiments were carried out during the two successive seasons of 2005 and 2006 at Banha (Qalubia Governorate) to study the effect of three rates of poultry manures $(50,75$ and $100 \mathrm{~N}$ unit/fed.) and the biofertilizer nitrogen (nitroben) on growth, yield, quality and chemical composition of squash. Obtained data showed that using $100 \mathrm{~N}$ unit/fed. from poultry manure gave the highest vegetative growth characters, yield and quality. Application $100 \mathrm{~N}$ unit/fed. from poultry manure also increased the nitrogen percentage and heavy metals in squash tissues. In addition, using nitroben biofertilizer gave the highest vegetative growth characters, yield, quality and nitrogen percentage. On the contrary, nitroben biofertilizer reduced the heavy metals in squash tissues
\end{abstract}

\section{INTRODUCTION}

Squash (Cucurbita pepo) is an important vegetable crop cultivated in Egypt for local market. Poultry manure has high percentages of $\mathrm{N}, \mathrm{P}, \mathrm{K}$ and microelements, which directly improve growth and yield of squash plant. Besides, it is a natural substrate for saprophytic microorganisms and provides nutrition to plants indirectly through the activation of soil microorganisms. In addition, organic fertilization is very important for providing the plants with their nutritional requirements without having any undesirable impacts on the environment. Al-Afifi et al (1991) found that organic manure enhanced growth and yield of squash plants. Nirmala and Vadivel (1999) showed that organic manure and biofertilizer gave the highest number of leaves per plant, dry matter production and fruit yield of cucumber plants. In addition, the best quality of cucumber fruits was obtained with organic manure (Kucinskas and Karbauskiene, 2000). Abdel-Mouty and Ali (2000) indicated that using the highest rate of chicken manure $\left(30 \mathrm{~m}^{3}\right)$ increased plant growth (plant length, number of leaves per plant, fresh and dry weight of leaves and shoots), yield and quality (fruit weight, length and diameter) in squash plants.

The bio-fertilizer has great amounts of symbiotic and non-symbiotic bacteria, which are responsible for fixation of $\mathrm{N}$ by atmosphere. Using biofertilizer increased vegetative growth characters (Awad \& Khalil, 2003 and Abdallah et al 2004 in cucumber plants), increasing yield and quality (Wang, 1998; Abd-El-Hafez \& Shehata, 2001; Yu-Zhan Dong \& Song and Su Yao, 2003) in cucumber plants). Moreover, biofertilizer enhanced dry weight and element uptake in cucumber plants (Deokar and Sawant, 2002) and increased nutrient contents in squash plants (Awad and Khalil, 2003).

The aim of this work was to study the effect of three rates of poultry manure and nitroben biofertilizer on growth, yield, quality and chemical composition of squash plants.

\section{MATERIAL AND METHODS}

Two field experiments were carried out during the two successive seasons of 2005 and 2006 at Banha (Qalubia Governorate) to investigate the effect of three rates of poultry manures $(50,75$ and $100 \mathrm{~N}$ unit/fed.) and nitroben biofertilizer at rates 
of 0 and $500 \mathrm{gm}$ per feddan on growth, yield, quality and chemical composition of squash plants local cv. Mabroka.

The biofertilizer nitroben was produced by General Organization for Agriculture Equaliztion Fund. The recommended dose for squash plant is $100 \mathrm{~N}$ unit/fed. Squash seeds were sown in the second week of April in 2005 and 2006 seasons, at distances of $40 \mathrm{~cm}$ between hills.

The physical and chemical properties of the experimental soil and poultry manure are presented in Table (1).

Table 1. Chemical analyses of the experimental soil and poultry manure.

\begin{tabular}{|lcccc|}
\hline \multirow{2}{*}{ Characters } & \multicolumn{2}{c}{2005} & \multicolumn{2}{c|}{2006} \\
\cline { 2 - 5 } & Soil & $\begin{array}{c}\text { Poultry } \\
\text { manure }\end{array}$ & Soil & $\begin{array}{c}\text { Poultry } \\
\text { manure }\end{array}$ \\
\hline PH & 7.85 & 7.77 & 7.89 & 7.62 \\
E.c (m.mohs) & 1.55 & 1.05 & 1.46 & 1.07 \\
Nitrogen \% & 0.15 & 2.64 & 0.22 & 2.36 \\
Phosphorus \% & 0.06 & 1.65 & 0.10 & 1.32 \\
Potassium \% & 0.14 & 2.17 & 0.11 & 2.09 \\
Fe ppm & 5844 & 2744 & 5133 & 2610 \\
$\mathrm{Zn} \mathrm{ppm}$ & 378 & 284 & 366 & 301 \\
$\mathrm{Mn} \mathrm{ppm}$ & 892 & 343 & 765 & 310 \\
Cu ppm & 40 & 1.5 & 37 & 1.4 \\
$\mathrm{~Pb}$ ppm & 41.5 & 110 & 39.5 & 108 \\
\hline
\end{tabular}

The design of the experiment was split-plot with four replicates, where the poultry manure rates were distributed in the main plots and the bio-fertilizer treatments were arranged in the subplots. The plot area was $11.2 \mathrm{~m}^{2}$ included 4 ridges, each with $70 \mathrm{~cm}$ width and $4.0 \mathrm{~m}$ long. The surface irrigation system was used in this experiment. The normal agricultural treatments of the growing squash were practiced as usually followed in the commercial production of squash. Poultry manure was added before sowing and the nitroben biofertilizer was added under the plants, at 15 days after sowing.

\section{Data recorded}

Samples of four plants were taken at 60 days after sowing and the plant length, number of leaves, stem diameter and fresh weight of leaves, stems and roots were recorded.

Samples of leaves, stems, roots and friuts were oven dried at $70^{\circ} \mathrm{C}$, then fine grounded and wet digested. Total nitrogen concentration in the tissues of plant roots, stems, leaves and fruits were determined according to the methods described by Jackson (1958). The $\mathrm{Fe}, \mathrm{Zn}, \mathrm{Mn}, \mathrm{Cu}$ and $\mathrm{Pb}$ contents were determined in dry roots, stems, leaves and fruits using Atomic Absorption Spectrophotometer, according to Jackson (1967).

Squash fruits were harvested twice every week. At harvest time, the fruit length, diameter and weight, and total weight of fruits in each experimental plot were recorded and the total yield was accounted. All the obtained data were subjected to statistical analysis of variance according to the procedure outlined by Gomez and Gomez (1984).

\section{RESULTS AND DISCUSSION}

\section{Vegetative growth characteristics}

\section{Effect of poultry manure}

Data in Table (2) show clearly that increasing poultry manure rate increased vegetative growth characters (plant length, leaf number, fresh and dry weight of roots, stems and leaves). The highest vegetative growth characters were recorded by $100 \mathrm{~N}$ unit poultry manure. Meanwhile, the lowest vegetative growth characters were recorded by 50 $\mathrm{N}$ unit poultry manure. These results were true in the two seasons of study. In addition, the stem diameter was not significantly affected by different poultry manure rates. Similar results were reported by Nirmala \& Vadivel (1999) and AlAfifi et al 1991.

\section{Effect of nitrogen biofertilizer (nitroben)}

As shown in Table (2), using biofertilizer increased significantly the vegetative growth characters (plant length, leaf number, fresh and dry weight of roots, stems and leaves) except for the stem diameter in both seasons. These findings were true in both seasons of study. These results are coincided with those reported by Yu-Zhan Dong \& Song-Su Yao (2003); Awad \& Khalil (2003) and Abdallah et al (2004). 
Table 2. Effect of poultry manure and nitrogen biofertilizer (Nitroben) zon vegetative growth characters of squash plants in 2005 and 2006 seasons

\begin{tabular}{|c|c|c|c|c|c|c|c|c|c|c|}
\hline \multirow{2}{*}{\multicolumn{2}{|c|}{ Treatments }} & \multirow{2}{*}{$\begin{array}{l}\text { Plant } \\
\text { length } \\
(\mathrm{cm})\end{array}$} & \multirow{2}{*}{$\begin{array}{c}\text { Leaf } \\
\text { number/ } \\
\text { plant }\end{array}$} & \multirow{2}{*}{$\begin{array}{c}\text { Stem } \\
\text { diameter } \\
(\mathrm{cm})\end{array}$} & \multicolumn{3}{|c|}{ Fresh weight $(\mathrm{g})$} & \multicolumn{3}{|c|}{ Dry weight $(\mathrm{g})$} \\
\hline & & & & & Leaves & Stems & Roots & Leaves & Stems & Roots \\
\hline \multicolumn{2}{|c|}{ Poultry manure } & \multicolumn{9}{|c|}{ First season } \\
\hline \multicolumn{2}{|c|}{$50 \mathrm{~N}$ unit } & 52.45 & 26.50 & 1.90 & 519.40 & 71.82 & 10.35 & 8.01 & 4.71 & 1.67 \\
\hline \multicolumn{2}{|c|}{$75 \mathrm{~N}$ unit } & 54.25 & 29.50 & 2.00 & 545.63 & 77.98 & 16.10 & 8.32 & 5.66 & 2.30 \\
\hline \multicolumn{2}{|c|}{$100 \mathrm{~N}$ unit } & 56.00 & 31.50 & 1.90 & 717.19 & 98.61 & 17.40 & 8.78 & 7.32 & 2.35 \\
\hline \multicolumn{2}{|c|}{ L.S.D } & \multicolumn{8}{|c|}{ Nitroben } & 0.13 \\
\hline \multicolumn{2}{|c|}{0 (Check) } & 48.73 & 27.00 & 1.93 & 553.89 & 69.20 & 12.81 & 8.00 & 5.52 & 1.99 \\
\hline \multicolumn{2}{|c|}{$500 \mathrm{~g} / \mathrm{fed}$} & 59.73 & 31.33 & 1.93 & 634.25 & 96.41 & 16.42 & 8.73 & 6.27 & 2.22 \\
\hline \multicolumn{2}{|c|}{ L.S.D } & \multicolumn{9}{|c|}{ Interaction } \\
\hline $50 \mathrm{~N}$ & 0 (Check) & 47.20 & 26.00 & 1.70 & 464.40 & 64.34 & 8.37 & 7.22 & 4.44 & 1.60 \\
\hline & $500 \mathrm{~g} / \mathrm{fed}$. & 57.70 & 27.00 & 2.10 & 574.40 & 79.30 & 12.33 & 8.79 & 4.98 & 1.73 \\
\hline $75 \mathrm{~N}$ & 0 (Check) & 50.00 & 26.00 & 2.20 & 475.65 & 60.02 & 14.55 & 8.20 & 5.64 & 2.14 \\
\hline unit & $500 \mathrm{~g} / \mathrm{fed}$. & 58.50 & 33.00 & 1.80 & 615.60 & 95.94 & 17.64 & 8.43 & 5.68 & 2.46 \\
\hline $100 \mathrm{~N}$ & 0 (Check) & 49.00 & 29.00 & 1.90 & 721.63 & 83.23 & 15.50 & 8.57 & 6.48 & 2.24 \\
\hline unit & $500 \mathrm{~g} / \mathrm{fed}$. & 63.00 & 34.00 & 1.90 & 712.75 & 113.99 & 19.30 & 8.98 & 8.15 & 2.46 \\
\hline \multicolumn{2}{|l|}{ L.S.D } & 4.50 & 1.23 & NS & 112.50 & 25.77 & NS & NS & NS & NS \\
\hline \multicolumn{2}{|c|}{ Poultry manure } & \multicolumn{9}{|c|}{ Second season } \\
\hline \multicolumn{2}{|c|}{$50 \mathrm{~N}$ unit } & 50.00 & 20.50 & 2.00 & 369.66 & 73.20 & 9.88 & 7.91 & 5.52 & 1.34 \\
\hline \multicolumn{2}{|c|}{$75 \mathrm{~N}$ unit } & 53.75 & 24.00 & 2.55 & 442.78 & 79.86 & 13.23 & 8.99 & 5.94 & 1.81 \\
\hline \multicolumn{2}{|c|}{$100 \mathrm{~N}$ unit } & 57.50 & 25.00 & 2.15 & 679.04 & 91.60 & 16.98 & 9.43 & 7.73 & 2.38 \\
\hline \multicolumn{2}{|c|}{ L.S.D } & \multicolumn{9}{|c|}{ Nitroben } \\
\hline \multicolumn{2}{|c|}{0 (Check) } & 51.00 & 21.33 & 2.33 & 479.84 & 75.56 & 12.22 & 8.64 & 6.10 & 1.79 \\
\hline \multicolumn{2}{|c|}{$500 \mathrm{~g} / \mathrm{fed}$} & 56.50 & 25.00 & 2.13 & 514.48 & 87.54 & 14.50 & 8.91 & 6.69 & 1.88 \\
\hline L.S.D & & 3.05 & 2.43 & NS & 25.22 & 6.45 & 1.5 & 0.12 & 0.26 & 0.05 \\
\hline Inter & tion & & & & & & & & & \\
\hline $50 \mathrm{~N}$ & 0 (Check) & 49.00 & 20.00 & 1.70 & 364.11 & 61.73 & 9.73 & 7.83 & 5.14 & 1.32 \\
\hline unit & $500 \mathrm{~g} / \mathrm{fed}$ & 51.00 & 21.00 & 2.30 & 375.21 & 84.66 & 10.03 & 7.99 & 5.90 & 1.35 \\
\hline $75 \mathrm{~N}$ & 0 (Check) & 50.00 & 21.00 & 3.00 & 389.20 & 77.28 & 12.40 & 8.78 & 5.85 & 1.77 \\
\hline unit & $500 \mathrm{~g} / \mathrm{fed}$. & 57.50 & 27.00 & 2.10 & 496.35 & 82.43 & 14.05 & 9.19 & 6.03 & 1.84 \\
\hline $100 \mathrm{~N}$ & 0 (Check) & 54.00 & 23.00 & 2.30 & 686.21 & 87.66 & 14.53 & 9.31 & 7.30 & 2.29 \\
\hline unit & $500 \mathrm{~g} / \mathrm{fed}$ & 61.00 & 27.00 & 2.00 & 671.87 & 95.53 & 19.43 & 9.55 & 8.15 & 2.46 \\
\hline L.S.D & & 6.14 & 1.65 & NS & 126.15 & 3.33 & 5.06 & 1.13 & 1.37 & NS \\
\hline
\end{tabular}

\section{Effect of the interaction}

The obtained data revealed that the interaction between poultry manure and biofertilizer (Table 2) significantly affected plant length, leaf number and fresh weight of stems and leaves in the first season. In addition, except for stem diameter and root dry weight, all tested growth characters were significantly affected in the second season. The highest values for plant height, leaf number and fresh weight of stems and leaves were recorded with 100 and $75 \mathrm{~N}$ unit combined with the biofertilizer in the two seasons of study. The heaviest dry weight of leaves was recorded with 75 and $100 \mathrm{~N}$ unit poultry manure with or without the biofertilizer in the second season. On the contrary, 
the lowest values of all vegetative growth characters were recorded by $50 \mathrm{~N}$ unit poultry manure without biofertilizer in the first season and second seasons.

\section{Total yield and quality}

\section{Effect of poultry manure}

As presented in Table (3), there were significant differences in the total yield and quality, among the different rates of poultry manure in the two seasons of study except for fruit diameter which failed to reach the $5 \%$ level of significance in the two seasons. The highest total yield and quality of squash fruits were produced by $100 \mathrm{~N}$ unit poultry manure treatment in the two seasons. On the contrary, the lowest total yield and quality of squash fruits plants were produced by $50 \mathrm{~N}$ unit poultry manure in the two seasons. These findings held good in both experimental seasons. The results are in accordance with those obtained by Nirmala \& Vadivel (1999); Al-Afifi et al (1991); Kucinskas \& Karbauskiene (2000); AbdelMouty \& Ali (2000) and Shi-Jiping et al (2003).

\section{Effect of biofertilizer (Nitroben)}

Data presented in Table (3) indicated that using the biofertilizer increased significantly the total yield and quality of squash fruits except for fruit diameter in both seasons. The highest total yield with the biofertilizer was 8.92 and 8.83 ton per feddan in the first and second seasons, respectively, compared with 8.5 and 8.23 ton per feddan without the application with the biofertilizer in the first and second seasons, respectively. Similar reports were recorded by Wang (1998) and AbdEl-Hafez \& Shehata (2001).

\section{Effect of the interaction}

The interaction between poultry manure levels and biofertilizer had significant effects on fruit yield, fruit length and average fruit weight but fruit diameter failed to reach the $5 \%$ level of significance in the two seasons. The highest total yield was recorded by $100 \mathrm{~N}$ unit poultry manure with biofertilizer in the first season and 100 or 75 $\mathrm{N}$ unit poultry manure with biofertilizer in the second season. The best quality, i.e., fruit length and average fruit weight, were recorded by $75 \mathrm{~N}$ unit poultry manure with biofertilizer and $100 \mathrm{~N}$ unit poultry manure with or without biofertilizer. These results held good in the two experimental seasons. On the contrary, the lowest total yield and quality of squash fruits were recorded with $50 \mathrm{~N}$ unit poultry manure without the biofertilizer in the two seasons.

Table 3. Effect of poultry manure and nitrogen biofertilizer (Nitroben) on yield and quality of squash plants in 2005 and 2006 seasons

\begin{tabular}{|c|c|c|c|c|c|c|c|c|c|}
\hline \multirow{3}{*}{\multicolumn{2}{|c|}{$\begin{array}{l}\text { Treatments } \\
\text { Poultry manure } \\
\end{array}$}} & $\begin{array}{c}\text { Total } \\
\text { yield } \\
\text { (ton/fed) }\end{array}$ & $\begin{array}{c}\text { Fruit } \\
\text { length } \\
(\mathrm{cm})\end{array}$ & $\begin{array}{c}\text { Fruit } \\
\text { diameter } \\
(\mathrm{cm})\end{array}$ & $\begin{array}{c}\text { Fruit } \\
\text { weight } \\
\text { (g) }\end{array}$ & $\begin{array}{c}\text { Total } \\
\text { yield } \\
\text { (ton/fed) }\end{array}$ & $\begin{array}{l}\text { Fruit } \\
\text { length } \\
(\mathrm{cm})\end{array}$ & $\begin{array}{c}\text { Fruit } \\
\text { diameter } \\
(\mathrm{cm})\end{array}$ & $\begin{array}{c}\text { Fruit } \\
\text { weight } \\
\text { (g) }\end{array}$ \\
\hline & & \multicolumn{4}{|c|}{2005} & \multicolumn{3}{|c|}{2006} & \\
\hline & & & & & & & & & \\
\hline \multicolumn{2}{|c|}{$50 \mathrm{~N}$ unit } & 8.48 & 12.29 & 3.19 & 114.38 & 8.24 & 12.74 & 3.37 & 124.05 \\
\hline \multicolumn{2}{|c|}{$75 \mathrm{~N}$ unit } & 8.60 & 13.40 & 3.19 & 132.24 & 8.79 & 13.01 & 3.40 & 141.17 \\
\hline \multicolumn{2}{|c|}{$100 \mathrm{~N}$ unit } & 8.92 & 13.79 & 3.30 & 136.26 & 8.83 & 13.31 & 3.44 & 145.36 \\
\hline \multicolumn{2}{|c|}{ L.S.D } & 0.11 & 0.26 & NS & 2.29 & 0.31 & 0.09 & NS & 3.22 \\
\hline \multicolumn{10}{|c|}{ Nitroben } \\
\hline \multicolumn{2}{|c|}{0 (Check) } & 8.50 & 13.08 & 3.20 & 125.32 & 8.32 & 12.90 & 3.37 & 133.01 \\
\hline \multicolumn{2}{|c|}{$500 \mathrm{~g} / \mathrm{fed}$} & 8.83 & 13.24 & 3.26 & 129.92 & 8.92 & 13.14 & 3.43 & 140.70 \\
\hline \multicolumn{2}{|c|}{ L.S.D } & 0.24 & 0.12 & NS & 2.29 & 0.14 & 0.07 & NS & 5.67 \\
\hline \multicolumn{10}{|c|}{ Interaction } \\
\hline \multirow{2}{*}{$\begin{array}{l}50 \mathrm{~N} \\
\text { unit }\end{array}$} & 0 (Check) & 8.43 & 12.22 & 3.15 & 112.52 & 8.13 & 12.66 & 3.36 & 121.42 \\
\hline & $500 \mathrm{~g} / \mathrm{fed}$ & 8.52 & 12.36 & 3.23 & 116.23 & 8.35 & 12.82 & 3.38 & 126.67 \\
\hline $75 \mathrm{~N}$ & 0 Check) & 8.67 & 13.38 & 3.18 & 128.12 & 8.25 & 12.78 & 3.35 & 135.12 \\
\hline \multicolumn{2}{|c|}{ unit $\quad 500 \mathrm{~g} / \mathrm{fed}$} & 8.53 & 13.42 & 3.20 & 136.35 & 9.32 & 13.24 & 3.44 & 147.22 \\
\hline \multirow{2}{*}{\multicolumn{2}{|c|}{$\begin{array}{lll}100 \mathrm{~N} & 0(\text { Check }) \\
\text { unit } & 500 \mathrm{~g} / \mathrm{fed}\end{array}$}} & 8.41 & 13.64 & 3.26 & 135.33 & 8.57 & 13.27 & 3.41 & 142.50 \\
\hline & & 9.43 & 13.93 & 3.34 & 137.18 & 9.08 & 13.35 & 3.46 & 148.22 \\
\hline \multicolumn{2}{|l|}{ L.S.D } & 0.12 & 0.45 & NS & 3.05 & 0.25 & 0.13 & NS & 5.23 \\
\hline
\end{tabular}




\section{Chemical composition}

\section{Effect of poultry manure}

Data in Tables $(4,5,6,7,8$ and 9) showed the effect of poultry manure on $\mathrm{N}, \mathrm{Fe}, \mathrm{Zn}, \mathrm{Mn}, \mathrm{Cu}$ and $\mathrm{Pb}$ in roots, stems, leaves and fruits. Generally, increasing poultry manure from $50 \mathrm{~N}$ unit unit to $100 \mathrm{~N}$ unit increased significantly $\mathrm{N}, \mathrm{Fe}, \mathrm{Zn}, \mathrm{Mn}$, $\mathrm{Cu}$ and $\mathrm{Pb}$ in roots, stems, leaves and fruits of squash plants except for $\mathrm{Cu}$ in roots in the second season which failed to reach the 5\% level of significance. The lowest values of the above elements were recorded with $50 \mathrm{~N}$ units poultry manure in the two seasons. We can notice that the lowest values of $\mathrm{N}, \mathrm{Fe}$ and $\mathrm{Mn}$ were found in fruits than in roots, stems and leaves. While, the lowest values of $\mathrm{Zn}, \mathrm{Cu}$ and $\mathrm{Pb}$ were recorded in stems and fruits than in roots and leaves. These results were true in the two seasons of study. The obtained results are in good agreement with that obtained by Shehata (2001).

\section{Effect of biofertilizer}

Data presented in Table (4) indicated that using biofertilizer increased significantly $\mathrm{N}$ percentage in roots, stems and leaves in the first season. On the other hand, $\mathrm{N}$ percentage in fruits in the first season and all plant tissues in the second season failed to reach the $5 \%$ level of significance.

The application of nitroben biofertilizer reduced significantly $\mathrm{Fe}$ in roots, stems and leaves whereas, Fe in fruits was not affected by the biofertilizer in the two seasons of study (Table 5). However, the biofertilizer had a significant effect on zinc only in stems in the first season, roots and stems in the second season (Table 6). In addition, $\mathrm{Mn}$ in roots in the first season and leaves in both seasons were affected significantly by biofertilizer (Table 7). Data in Table (8) showed that the effect of the biofertilizer on $\mathrm{Cu}$ was significant only in leaves in the first season while $\mathrm{Cu}$ in the other tissues of squash plant failed to

Table 4. Effect of poultry manure and nitrogen biofertilizer (Nitroben) on N\% in roots, stems, leaves and fruits of squash plants in 2005 and 2006 seasons

\begin{tabular}{|c|c|c|c|c|c|c|c|c|c|}
\hline \multirow{2}{*}{\multicolumn{2}{|c|}{ Treatments }} & Roots & Stems & Leaves & Fruits & Roots & Stems & Leaves & Fruits \\
\hline & & \multicolumn{4}{|c|}{2005} & \multicolumn{4}{|c|}{2006} \\
\hline \multicolumn{10}{|c|}{ Levels of poultry manure } \\
\hline \multicolumn{2}{|c|}{$50 \mathrm{~N}$ unit } & 2.15 & 1.96 & 1.99 & 1.74 & 1.92 & 1.88 & 1.83 & 1.68 \\
\hline \multicolumn{2}{|c|}{$75 \mathrm{~N}$ unit } & 2.21 & 2.04 & 2.08 & 1.77 & 2.05 & 1.91 & 1.89 & 1.76 \\
\hline \multicolumn{2}{|c|}{$100 \mathrm{~N}$ unit } & 2.31 & 2.21 & 2.24 & 1.86 & 2.14 & 2.04 & 2.06 & 1.92 \\
\hline \multicolumn{2}{|l|}{ L.S.D } & 0.13 & 0.15 & 0.09 & 0.08 & 0.15 & 0.09 & 0.11 & 0.09 \\
\hline \multicolumn{10}{|l|}{ Nitroben } \\
\hline \multicolumn{2}{|c|}{0 (Check) } & 2.18 & 2.02 & 2.06 & 1.76 & 2.00 & 1.91 & 1.90 & 1.73 \\
\hline \multicolumn{2}{|c|}{$500 \mathrm{~g} / \mathrm{fed}$} & 2.26 & 2.11 & 2.14 & 1.81 & 2.07 & 1.97 & 1.95 & 1.83 \\
\hline \multicolumn{2}{|l|}{ L.S.D } & 0.06 & 0.04 & 0.06 & NS & NS & NS & NS & NS \\
\hline \multicolumn{10}{|c|}{ Interaction } \\
\hline \multirow{2}{*}{$\begin{array}{ll}50 & \mathrm{~N} \\
\text { unit } & \end{array}$} & 0 (Check) & 2.11 & 1.92 & 1.97 & 1.72 & 1.96 & 1.85 & 1.83 & 1.64 \\
\hline & $500 \mathrm{~g} / \mathrm{fed}$. & 2.19 & 2.00 & 2.00 & 1.75 & 1.88 & 1.91 & 1.82 & 1.71 \\
\hline \multirow{2}{*}{$\begin{array}{ll}75 & \mathrm{~N} \\
\text { unit } & \end{array}$} & 0 (Check) & 2.16 & 1.98 & 2.05 & 1.75 & 1.98 & 1.89 & 1.85 & 1.69 \\
\hline & $500 \mathrm{~g} / \mathrm{fed}$ & 2.26 & 2.09 & 2.11 & 1.79 & 2.12 & 1.92 & 1.92 & 1.83 \\
\hline \multirow{2}{*}{$\begin{array}{l}100 \\
\text { unit }\end{array}$} & 0 (Check) & 2.28 & 2.17 & 2.16 & 1.82 & 2.06 & 1.99 & 2.01 & 1.87 \\
\hline & $500 \mathrm{~g} / \mathrm{fed}$. & 2.33 & 2.24 & 2.31 & 1.90 & 2.21 & 2.08 & 2.11 & 1.96 \\
\hline \multicolumn{2}{|l|}{ L.S.D } & NS & NS & NS & NS & NS & NS & $\mathrm{NS}$ & NS \\
\hline
\end{tabular}


Table 5. Effect of poultry manure and nitrogen biofertilizer (Nitroben) on Fe (p.p.m) in roots, stems, leaves and fruits of squash plants in 2005 and 2006 seasons.

\begin{tabular}{|c|c|c|c|c|c|c|c|c|c|}
\hline \multirow{2}{*}{\multicolumn{2}{|c|}{ Treatments }} & Roots & Stems & Leaves & Fruits & Roots & Stems & Leaves & Fruits \\
\hline & & \multicolumn{4}{|c|}{2005} & \multicolumn{4}{|c|}{2006} \\
\hline \multicolumn{10}{|c|}{ Poultry manure } \\
\hline \multicolumn{2}{|c|}{$50 \mathrm{~N}$ unit } & 1634 & 1415 & 1226 & 1126 & 1682 & 1421 & 1028 & 897 \\
\hline \multicolumn{2}{|c|}{$75 \mathrm{~N}$ unit } & 1782 & 1530 & 1488 & 1302 & 1729 & 1605 & 1369 & 1195 \\
\hline & 1922 & 1796 & 1605 & 1376 & 1928 & 1733 & 1705 & 1309 \\
\hline \multicolumn{2}{|c|}{ L.S.D } & 117 & 82 & 46 & 88 & 33 & 109 & 166 & 106 \\
\hline \multicolumn{10}{|c|}{ Nitroben } \\
\hline \multicolumn{2}{|c|}{0 (Check) } & 1856 & 1619 & 1465 & 1315 & 1820 & 1603 & 1489 & 1143 \\
\hline \multicolumn{2}{|c|}{$500 \mathrm{~g} / \mathrm{fed}}$. & 1703 & 1542 & 1415 & 1221 & 1740 & 1570 & 1245 & 1124 \\
\hline \multicolumn{2}{|l|}{ L.S.D } & 34 & 22 & 47 & NS & 37 & 28 & 91 & NS \\
\hline \multicolumn{10}{|c|}{ Interaction } \\
\hline \multirow{2}{*}{\multicolumn{2}{|c|}{$\begin{array}{ll}50 \mathrm{~N} & 0 \text { (Check) } \\
\text { unit } & 500 \mathrm{~g} / \mathrm{fed}\end{array}$}} & 1755 & 1486 & 1224 & 1139 & 1740 & 1468 & 965 & 788 \\
\hline & $500 \mathrm{~g} / \mathrm{fed}$. & 1514 & 1345 & 1228 & 1113 & 1625 & 1375 & 1091 & 1006 \\
\hline \multicolumn{2}{|c|}{$75 \mathrm{~N} \quad 0$ (Check) } & 1838 & 1509 & 1544 & 1369 & 1811 & 1623 & 1692 & 1284 \\
\hline \multicolumn{2}{|c|}{ unit $\quad 500 \mathrm{~g} / \mathrm{fed}$. } & 1726 & 1551 & 1432 & 1235 & 1648 & 1587 & 1046 & 1107 \\
\hline \multirow{2}{*}{$\begin{array}{l}100 \mathrm{~N} \\
\text { unit }\end{array}$} & 0 (Check) & 1975 & 1862 & 1626 & 1437 & 1909 & 1719 & 1810 & 1357 \\
\hline & $500 \mathrm{~g} / \mathrm{fed}$ & 1870 & 1730 & 1585 & 1315 & 1947 & 1748 & 1599 & 1261 \\
\hline \multicolumn{2}{|l|}{ L.S.D } & NS & NS & NS & NS & NS & NS & NS & NS \\
\hline
\end{tabular}

Table 6. Effect of poultry manure and nitrogen biofertilizer (Nitroben) on $\mathrm{Zn}$ (ppm) in roots, stems, leaves and fruits of squash plants in 2005 and 2006 seasons.

\begin{tabular}{|c|c|c|c|c|c|c|c|c|c|}
\hline \multirow{2}{*}{\multicolumn{2}{|c|}{ Treatments }} & Roots & Stems & Leaves & Fruits & Roots & Stems & Leaves & Fruits \\
\hline & & \multicolumn{4}{|c|}{2005} & \multicolumn{4}{|c|}{2006} \\
\hline \multicolumn{10}{|c|}{ Poultry manure } \\
\hline \multicolumn{2}{|c|}{$50 \mathrm{~N}$ unit } & 57.28 & 71.65 & 85.55 & 79.78 & 78.33 & 76.88 & 57.35 & 61.88 \\
\hline \multicolumn{2}{|c|}{$75 \mathrm{~N}$ unit } & 73.78 & 79.60 & 100.03 & 84.28 & 81.75 & 102.93 & 85.50 & 71.28 \\
\hline \multicolumn{2}{|c|}{$100 \mathrm{~N}$ unit } & 103.33 & 123.85 & 103.18 & 91.73 & 102.73 & 117.28 & 108.80 & 100.40 \\
\hline \multicolumn{2}{|l|}{ L.S.D } & 10.13 & 3.58 & 13.15 & 3.67 & 6.5 & 1.05 & 16.7 & 8.87 \\
\hline \multicolumn{10}{|c|}{ Nitroben } \\
\hline \multicolumn{2}{|c|}{0 (Check) } & 78.08 & 97.20 & 97.77 & 85.63 & 92.90 & 101.62 & 84.17 & 80.00 \\
\hline \multicolumn{2}{|c|}{$500 \mathrm{~g} / \mathrm{fed}}$. & 78.17 & 86.20 & 94.73 & 84.88 & 82.30 & 96.43 & 83.60 & 75.70 \\
\hline \multicolumn{2}{|c|}{ L.S.D } & NS & 3.24 & NS & NS & 5.66 & 2.34 & NS & NS \\
\hline \multicolumn{10}{|c|}{ Interaction } \\
\hline \multirow{2}{*}{$\begin{array}{l}50 \mathrm{~N} \\
\text { unit }\end{array}$} & 0 (Check) & 58.30 & 84.00 & 88.70 & 78.25 & 79.50 & 80.65 & 53.75 & 64.65 \\
\hline & $500 \mathrm{~g} / \mathrm{fed}$. & 56.25 & 59.30 & 82.40 & 81.30 & 77.15 & 73.10 & 60.95 & 59.10 \\
\hline \multirow{2}{*}{$\begin{array}{l}75 \mathrm{~N} \\
\text { unit }\end{array}$} & 0 (Check) & 76.05 & 86.55 & 108.50 & 84.90 & 86.00 & 104.15 & 82.30 & 71.65 \\
\hline & $500 \mathrm{~g} / \mathrm{fed}$. & 71.50 & 72.65 & 91.55 & 83.65 & 77.50 & 101.70 & 88.70 & 70.90 \\
\hline $\begin{array}{l}\text { unit } \\
100 \mathrm{~N}\end{array}$ & 0 (Check) & 99.90 & 121.05 & 96.10 & 93.75 & 113.20 & 120.05 & 116.45 & 103.70 \\
\hline \multicolumn{2}{|r|}{$500 \mathrm{~g} / \mathrm{fed}}$. & 106.75 & 126.65 & 110.25 & 89.70 & 92.25 & 114.50 & 101.15 & 97.10 \\
\hline \multicolumn{2}{|l|}{ L.S.D } & NS & NS & NS & NS & NS & NS & NS & NS \\
\hline
\end{tabular}


Table 7. Effect of poultry manure and nitrogen biofertilizer (Nitroben) on Mn (p.p.m) in roots, stems, leaves and fruits of squash plants in 2005 and 2006 seasons.

\begin{tabular}{|c|c|c|c|c|c|c|c|c|c|}
\hline \multirow{2}{*}{\multicolumn{2}{|c|}{ Treatments }} & Roots & Stems & Leaves & Fruits & Roots & Stems & Leaves & Fruits \\
\hline & & \multicolumn{4}{|c|}{2005} & \multicolumn{4}{|c|}{2006} \\
\hline \multicolumn{10}{|c|}{ Poultry manure } \\
\hline \multicolumn{2}{|c|}{$50 \mathrm{~N}$ unit } & 251.50 & 104.00 & 152.75 & 50.75 & 243.75 & 76.16 & 95.75 & 45.25 \\
\hline \multicolumn{2}{|c|}{$75 \mathrm{~N}$ unit } & 282.75 & 119.50 & 167.25 & 55.04 & 264.75 & 87.25 & 134.00 & 55.25 \\
\hline \multicolumn{2}{|c|}{$100 \mathrm{~N}$ unit } & 378.25 & 135.50 & 180.50 & 66.25 & 314.50 & 94.25 & 146.75 & 58.75 \\
\hline \multicolumn{2}{|c|}{ L.S.D } & 2.24 & 11.35 & 7.87 & 3.44 & 14.55 & 4.50 & 8.40 & 2.36 \\
\hline \multicolumn{10}{|c|}{ Nitroben } \\
\hline \multirow{2}{*}{\multicolumn{2}{|c|}{$\begin{array}{l}0 \text { (Check) } \\
500 \mathrm{~g} / \text { fed. }\end{array}$}} & 310.83 & 120.17 & 169.67 & 57.52 & 273.67 & 86.33 & 131.33 & 55.33 \\
\hline & & 297.50 & 119.17 & 164.00 & 57.17 & 275.00 & 85.44 & 119.67 & 50.83 \\
\hline \multicolumn{2}{|c|}{ L.S.D } & 3.05 & NS & 1.58 & NS & NS & NS & 6.67 & NS \\
\hline \multicolumn{10}{|c|}{ Interaction } \\
\hline $50 \mathrm{~N}$ & 0 (Check) & 225.50 & 112.00 & 157.00 & 44.00 & 250.00 & 74.00 & 98.50 & 46.50 \\
\hline & $500 \mathrm{~g} / \mathrm{fed}$ & 277.50 & 96.00 & 148.50 & 57.50 & 237.50 & 78.32 & 93.00 & 44.00 \\
\hline $75 \mathrm{~N}$ & 0 (Check) & 352.50 & 112.00 & 166.50 & 59.07 & 247.50 & 92.00 & 140.50 & 56.00 \\
\hline unit & $500 \mathrm{~g} / \mathrm{fed}$ & 213.00 & 127.00 & 168.00 & 51.00 & 282.00 & 82.50 & 127.50 & 54.50 \\
\hline $100 \mathrm{~N}$ & 0 (Check) & 354.50 & 136.50 & 185.50 & 69.50 & 323.50 & 93.00 & 155.00 & 63.50 \\
\hline unit & $500 \mathrm{~g} / \mathrm{fed}$ & 402.00 & 134.50 & 175.50 & 63.00 & 305.50 & 95.50 & 138.50 & 54.00 \\
\hline \multicolumn{2}{|c|}{ L.S.D } & NS & NS & NS & NS & NS & NS & NS & NS \\
\hline
\end{tabular}

Table 8. Effect of poultry manure and nitrogen biofertilizer (Nitroben) on $\mathrm{Cu}$ (p.p.m) in roots, stems, leaves and fruits of squash plants in 2005 and 2006 seasons.

\begin{tabular}{|c|c|c|c|c|c|c|c|c|}
\hline \multirow{2}{*}{ Treatments } & Roots & Stems & Leaves & Fruits & Roots & Stems & Leaves & Fruits \\
\hline & \multicolumn{4}{|c|}{2005} & \multicolumn{4}{|c|}{2006} \\
\hline \multicolumn{9}{|l|}{ Poultry manure } \\
\hline $50 \mathrm{~N}$ unit & 21.25 & 14.75 & 17.00 & 15.00 & 34.25 & 8.75 & 15.00 & 13.75 \\
\hline $75 \mathrm{~N}$ unit & 23.50 & 18.25 & 22.25 & 18.00 & 35.75 & 12.50 & 28.00 & 15.00 \\
\hline $100 \mathrm{~N}$ unit & 40.00 & 25.00 & 37.75 & 20.00 & 37.00 & 24.73 & 29.75 & 18.00 \\
\hline L.S.D & 2.04 & 2.77 & 3.44 & 1.73 & NS & 1.57 & 1.52 & 0.76 \\
\hline \multicolumn{9}{|l|}{ Nitroben } \\
\hline 0 (Check) & 29.00 & 19.17 & 29.00 & 17.67 & 37.50 & 15.33 & 24.33 & 16.17 \\
\hline $500 \mathrm{~g} / \mathrm{fed}$. & 27.50 & 19.50 & 22.33 & 17.67 & 33.83 & 15.32 & 24.17 & 15.00 \\
\hline L.S.D & NS & NS & 6.92 & NS & NS & NS & NS & NS \\
\hline \multicolumn{9}{|l|}{ Interaction } \\
\hline $50 \quad \mathrm{~N} 0$ (Check) & 23.50 & 17.00 & 18.50 & 16.50 & 38.00 & 9.00 & 14.50 & 12.00 \\
\hline unit $\quad 500 \mathrm{~g} / \mathrm{fed}$. & 19.00 & 12.50 & 15.50 & 13.50 & 30.50 & 8.50 & 15.50 & 15.50 \\
\hline $75 \quad \mathrm{~N} \quad 0$ (Check) & 29.50 & 17.00 & 25.00 & 16.00 & 36.00 & 16.00 & 26.00 & 13.50 \\
\hline unit $\quad 500 \mathrm{~g} / \mathrm{fed}$ & 17.50 & 19.50 & 19.50 & 20.00 & 35.50 & 9.00 & 30.00 & 16.50 \\
\hline $100 \mathrm{~N} 0$ (Check) & 34.00 & 23.50 & 43.50 & 20.50 & 38.50 & 21.00 & 32.50 & 23.00 \\
\hline unit $\quad 500 \mathrm{~g} / \mathrm{fed}$. & 46.00 & 26.50 & 32.00 & 19.50 & 35.50 & 28.45 & 27.00 & 13.00 \\
\hline L.S.D & NS & NS & NS & NS & NS & NS & NS & NS \\
\hline
\end{tabular}


Table 9. Effect of poultry manure and nitrogen biofertilizer (Nitroben) on $\mathrm{Pb}$ (p.p.m) in roots, stems, leaves and fruits of squash plants in 2005 and 2006 seasons.

\begin{tabular}{|c|c|c|c|c|c|c|c|c|c|}
\hline \multirow{2}{*}{\multicolumn{2}{|c|}{ Treatments }} & Roots & Stems & Leaves & Fruits & Roots & Stems & Leaves & Fruits \\
\hline & & \multicolumn{4}{|c|}{2005} & \multicolumn{4}{|c|}{2006} \\
\hline \multicolumn{10}{|c|}{ Poultry manure } \\
\hline \multicolumn{2}{|c|}{$50 \mathrm{~N}$ unit } & 4.58 & 3.35 & 4.48 & 4.43 & 4.31 & 4.93 & 3.13 & 3.38 \\
\hline \multicolumn{2}{|c|}{$75 \mathrm{~N}$ unit } & 5.98 & 6.75 & 5.93 & 6.23 & 6.00 & 7.15 & 5.80 & 5.30 \\
\hline \multicolumn{2}{|c|}{$100 \mathrm{~N}$ unit } & 6.48 & 9.74 & 6.75 & 7.93 & 8.30 & 10.53 & 7.48 & 7.13 \\
\hline \multicolumn{2}{|c|}{ L.S.D } & 0.51 & 1.13 & 0.55 & 1.45 & 1.37 & 2.23 & 0.98 & 1.16 \\
\hline \multicolumn{10}{|c|}{ Nitroben } \\
\hline \multicolumn{2}{|c|}{0 (Check) } & 5.68 & 4.98 & 5.78 & 7.17 & 6.29 & 8.18 & 4.37 & 5.78 \\
\hline \multicolumn{2}{|c|}{$500 \mathrm{~g} / \mathrm{fed}}$. & 5.67 & 8.24 & 5.65 & 5.22 & 6.12 & 6.88 & 6.57 & 4.75 \\
\hline \multicolumn{2}{|c|}{ L.S.D } & NS & NS & NS & NS & 0.15 & NS & NS & NS \\
\hline \multicolumn{10}{|c|}{ Interaction } \\
\hline \multirow{2}{*}{\multicolumn{2}{|c|}{$50 \quad \mathrm{~N} \quad 0$ (Check) }} & 3.90 & 1.20 & 3.80 & 4.75 & 4.06 & 4.05 & 2.95 & 3.55 \\
\hline & & 5.25 & 5.50 & 5.15 & 4.10 & 4.55 & 5.80 & 3.30 & 3.20 \\
\hline \multicolumn{2}{|c|}{$\begin{array}{lll}\text { unit } & & 500 \mathrm{~g} / \mathrm{fed} . \\
75 & \mathrm{~N} & 0(\text { Check })\end{array}$} & 6.40 & 8.75 & 5.95 & 6.85 & 5.65 & 9.40 & 5.85 & 5.95 \\
\hline \multicolumn{2}{|c|}{ unit $\quad 500 \mathrm{~g} / \mathrm{fed}$. } & 5.55 & 4.75 & 5.90 & 5.60 & 6.35 & 4.90 & 5.75 & 4.65 \\
\hline \multirow{2}{*}{\multicolumn{2}{|c|}{$\begin{array}{lll}100 \mathrm{~N} & 0(\text { Check }) \\
\text { unit } & & 500 \mathrm{~g} / \mathrm{fed} .\end{array}$}} & 6.75 & 5.00 & 7.60 & 9.90 & 9.15 & 11.10 & 4.30 & 7.85 \\
\hline & & 6.20 & 14.47 & 5.90 & 5.95 & 7.45 & 9.95 & 10.65 & 6.40 \\
\hline \multicolumn{2}{|l|}{ L.S.D } & NS & NS & $\mathrm{NS}$ & $\mathrm{NS}$ & $\mathrm{NS}$ & NS & NS & $\mathrm{NS}$ \\
\hline
\end{tabular}

reach the 5\% level of significance. The effect of biofertilizer on $\mathrm{Pb}$ was significant only in roots in the second season. (Table 9).

Generally, we can report that using biofertilizer reduced the heavy metals in the different squash plants tissues. The results are in accordance with those obtained by Deokar and Sawant (2002) and Awad and Khalil (2003).

\section{Effect of the interaction}

Data in Tables $(4,5,6,7$ and 8) revealed that the interaction between different rates of poultry manure and nitroben biofertilizer had no significant effects on $\mathrm{Fe}, \mathrm{Zn}, \mathrm{Mn}, \mathrm{Cu}$ and $\mathrm{Pb}$ in roots, stems, leaves and fruits in the two seasons of study. These results were true in the two seasons of study.

\section{CONCLUSION}

Using $100 \mathrm{~N}$ units from poultry manure with nitrogen biofertilizer gave the highest vegetative growth characters, yield and quality. In addition, using nitrogen biofertilizer increased nitrogen percentage and reduced the heavy metals in squash tissues.

\section{REFERENCE}

Abdallah, A.R.; A.M.M. Hammad; O.A.O. Saad and S.H. Fathy (2004). Alginate entrapped $\mathrm{N} 2$ fixing and $\mathrm{P}$ dissolving bacteria as a phage resistant form of biofertilizers. Arab Univ. J. Agric. Sci. , Cairo, 12 (1): 117-136.

Abd-El-Hafez, A.E. and S.F. Shehata (2001). Field evaluation of yeasts as a biofertilizer for some vegetable crops. Arab Univ. J. Agric. Sci., Cairo, 9 (1): 169-182.

Abdel-Mouty, M.M. and A.H. Ali. 2000. Sources and levels of organic manure fertilizer affecting growth and yield of squash (Cucurbita реро, L.). Egypt. J. Appl. Sci. 15 (11): 263-281.

Al-Afifi, M.A; A. Al-Masoum; M.E. Shawky; A.M. El-Berry; A.G. El-Sayed and I.M. Gharib. 1991. Preliminary studies on testing soil conditioners for vegetable use in UAE. Bulletin of Faculty of Agric. Univ. of Cairo. 42 (3): 10611077.

Awad, N.M. and K. Khalil (2003). Biofertilization of squash plants grown in sulphur rectified sandy soil with Streptomyces venezuelae mutant and or Thiobacillus thiooxidans. Bulletin of the National Research Center, Cairo 28(6): 685694. 
Deokar, K.P. and D.M. Sawant (2002). Inhibition of cucumber mosaic virus in chilli by biofertilizers. Agricultural Journal of Maharashtra, 26 (3): 276-279.

Gomez, K.A. and A.A. Gomez (1984). Statistical Procedures for Agricultural Research. $2^{\text {nd }}$ Ed., PP. 357-423. Wiley Inter Science Pulb., N.Y. Jakson, M.L. (1958). Soil Chemical Analysis Prentice. Hall, Inc., Englewood Cliffs, N.J. USA. Jackson, M.L. (1967). Soil Chemical Analysis. Prentice- Hall of India Private Limited, New Delhi.

Kucinskas, J. and E. Karbauskiene (2000). Cucumber fertilization by vermicompost. Sodininkyste-ir-Darzininkyste. 19(3(2)): 46-54.

Nirmala, R. and E. Vadivel (1999). Effect of combined application of organic manure and biofertilizers on growth and productivity of cucum- ber. South Indian Horticultural 47(1:6):252254.

Shehata, S.M. (2001). Effect of some organic wastes application on growth, chemical contents and yield of squash plant. J. Agric. Sci. Mansoura Univ., 26 (9): 5695-5704.

Shi-Jiping; Dong-Yonghua and Yao-Yongkang (2003). Comparison of organic manure and fertilizer in organic soilless culture. Acta Agriculturae- Shanghai 19 (3): 76-79.

Wang, Q.I. (1998). Study on application of biofertilizer to transplant cucumber in the sunny greenhouse. Journal of Jilin Agricultural University 20 (3): 75-77.

Yu-Zhan Dong and Song- Su Yao (2003). Effect of straw mixed with biopreparate on improvement of soil in greenhouse. Chinese Society of Agricultural Engineering 19 (1): 177-179.
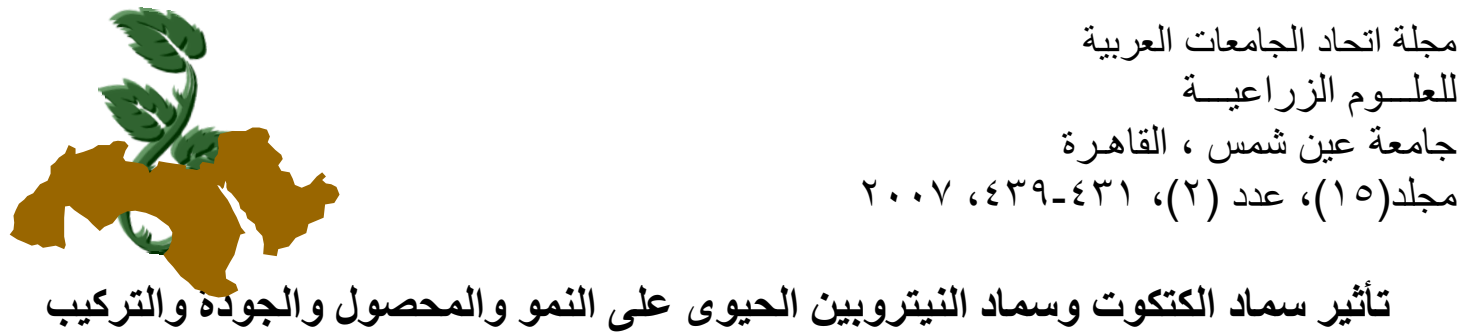

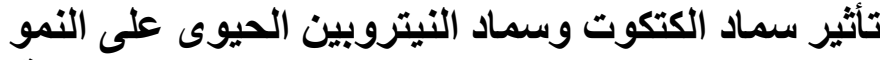 الكيميائى لنباتات الكوسة الني النئ}

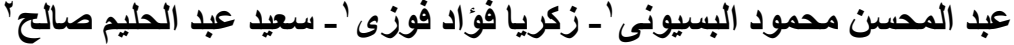

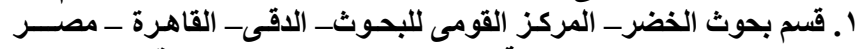

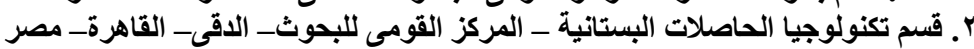

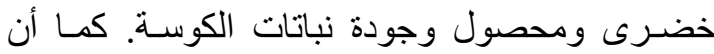

$$
\begin{aligned}
& \text { أجريت تجربتان حقليتان فى منطقة بنها (محافظة }
\end{aligned}
$$

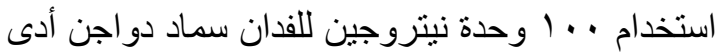

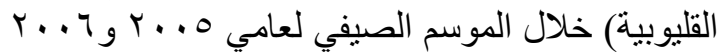

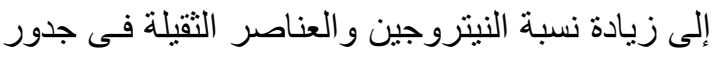

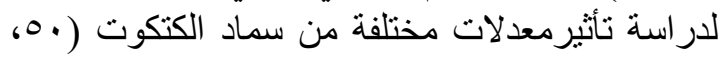

$$
\begin{aligned}
& \text { وسيقان وأوراق وثمار نباتات الكوســة الكئ. } \\
& \text { استخدام سماد النيتروبين الحيوى أعطى أعلى نمو نمو } \\
& \text { 0 0 . . . وحدة نيتروجين للفدان) و إستخدام السماد } \\
& \text { الحيوى النيتروبين على النمو و المحصول و والجودة } \\
& \text { و التركيب الكيميائى لنباتات الكوسة. } \\
& \text { إلى تقليل العناصر ومحصول وجنودة ونسبة النينزو في جدور و سيقان و اوراق ادى } \\
& \text { وثمار نباتات الكوسة. }
\end{aligned}
$$

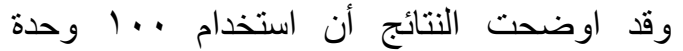

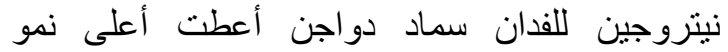

$$
\begin{aligned}
& \text { ا.د سيد محمود سنجر } \\
& \text { تحكيم: ا.د إبراهيم إبراهيم العكش }
\end{aligned}
$$

